\title{
A Linguistic Analysis of Petroleum-Related English Research Article Titles
}

\author{
Yulia A. Filyasova \\ Saint-Petersburg University of Management Technologies and Economics \\ Lermontovsky prospect, 44A, Saint-Petersburg, Russia 190103
}

Research article titles constitute a special type of text - concise, clear, and informative. The specificity of article titles is determined by a number of factors such as the object of research, the author's personal style, academic tradition, the field of study among them. Today, article titles from different scientific areas are in the focus of scientific attention. This article presents the results of a linguistic analysis aimed at determining similarities and differences of research article titles from journals on petroleum science. The theoretical value has the descriptive analysis of technical article titles which can further be compared with titles from other areas of research. According to the obtained results, the titles were 15 words on average. The overwhelming majority (98\%) of the titles had a nominative character; $2 \%$ were subject-predicate sentences, mainly, interrogative. Words were seven characters long, on average. Nouns, function words and adjectives were the most frequently occurred word classes; on the contrary, numerals, adverbs and verbs - the least frequent words. The most common punctuation marks were hyphens, commas, and colons, indicating the complexity of technical terms, enumeration and elaboration of the object of research and geography of petroleum sites. Names of petroleum reservoirs, formations and basins with their location specification, multisyllabic professional terms and abbreviations, constituting $30 \%$ of the article titles' lengths on the average, can be considered special features of article titles on petroleum science. For this reason, a long title is typical of petroleum-related research articles. Additionally, more articles were devoted to richer petroleum reserves.

Key words: article titles, number of words in article titles, punctuation marks, technical terms, petroleum, quantitative analysis, title length. linguistic analysis

\section{Article history:}

Received: 01.012.2019

Accepted: 15.12.2019

\section{For citation:}

Filyasova Yu.A. (2020). A Linguistic Analysis of Petroleum-Related English Research Article Titles. RUDN Journal of Language Studies, Semiotics and Semantics,11(1), 120-134. doi: 10.22363/2313-2299-2020-11-1-120-134.

(C) Филясова Ю.А., 2020

(c) () This work is licensed under a Creative Commons Attribution 4.0 International License https://creativecommons.org/licenses/by/4.0/ 
Удк: 81'276.6:62

\title{
Лингвистический анализ английских названий научных статей по нефтегазовой тематике
}

\author{
Ю.А. Филясова \\ Санкт-Петербургский университет технологий управления и экономики \\ Лермонтовский проспект, 44A, г. Санкт-Петербург, Россия, 190103
}

\begin{abstract}
Названия научных статей представляют собой особый вид текста — краткий, понятный и информативный. Особенность заголовков статей определяется несколькими факторами, такими как объект исследования, персональный стиль автора, академическая традиция, а также область исследования. Сегодня заголовки статей из разных областей знаний находятся в фокусе внимания исследователей. В данной статье представлены результаты лингвистического анализа, нацеленного на определение сходств и различий названий научных статей из журналов по нефтегазовой тематике. Теоретическая значимость заключается в дескриптивном анализе названий технических статей, которые в дальнейшем могут быть сопоставлены с заголовками статей из других областей науки. Согласно полученным данным, длина названий составляет, в среднем, 15 слов. Подавляющее большинство (98\%) названий носит номинативный характер; $2 \%$ имеют субъектно-предикатную структуру, будучи в основном, вопросительными. Средняя длина слов около 7 символов. Существительные, служебные слова и прилагательные стали наиболее частотными частями речи; напротив, числительные, наречия и глаголы - наименее частотными. Самыми распространенными пунктуационными знаками оказались дефис, запятая и двоеточие, указывающие на сложность технических терминов, перечисление и разъяснение объектов исследования, и географическое положение нефтяных месторождений. Названия нефтяных коллекторов, формаций и бассейнов, их местоположение, многосложные профессиональные термины и аббревиатуры, в среднем составляющие $30 \%$ от длины названий статей, могут рассматриваться в качестве особенностей заголовков статей по нефтегазовой тематике. По этой причине, названия таких статей, как правило, объемны. Кроме того, большее количество статей посвящено более крупным нефтегазовым месторождениям.
\end{abstract}

Ключевые слова: названия статей, длина заголовка статьи, лингвистический анализ, пунктуационные знаки, технические термины, нефть, количественный анализ

\section{История статьи:}

Дата поступления: 01.012.2019

Дата принятия в печать: 15.12.2019

\section{Для цитирования:}

Филясова Ю.А. Лингвистический анализ английских названий научных статей по нефтегазовой тематике // Вестник Российского университета дружбы народов. Серия: Теория языка. Семиотика. Семантика, 2020. Т 11. nо 1. С. 120-134. doi: 10.22363/2313-2299-2020-11-1120-134.

\section{Introduction}

Title is a means of efficiently communicating scientific findings to the broad community of scientists in a uniform manner. Titles of academic papers are of interest to researchers from the linguistic and interlinguistic points of view [1-5]. C. Fox and C. Burns state that titles of manuscripts became marginally longer, broader in focus (less frequent inclusion of genus and species names), and included more humor and 
subtitles over the period of the study [6. P. 1970]. V. Soler notes that the full-sentence title construction appears as a generic peculiarity of research papers [7. P. 90].

Article titles are also in the focus of research from a practical viewpoint. A. Letchford, H. Moat, T. Preis provide evidence that journals which publish papers with shorter titles receive more citations per paper. These results are consistent with the intriguing hypothesis that papers with shorter titles may be easier to understand, and hence attract more citations [8; 9. P. 653]. Title length is sometimes related to the article quality [10].

The aim of this paper is formal linguistic analysis of English scientific article titles on petroleum science. The theoretical value has the descriptive analysis of technical article titles which can further be compared with titles from other areas of research.

\section{Material}

700 titles of research articles were analyzed from the following international journals, included in online platforms Elsevier, Wiley, Springer, EAGE (the European Association of Geoscientists and Engineers): 1) Journal of Petroleum Geology (the UK); 2) Petroleum Geoscience (the UK); 3) Journal of Unconventional Oil and Gas Resources (the UK); 4) Journal of Petroleum Science and Engineering (the Netherlands); 5) Marine and Petroleum Geology (the Netherlands); 6) Petroleum Exploration and Development (China); 7) Petroleum Science (China). For the convenience of study, the journals were abbreviated as follows: JPG, PG, JUOGR, JPSE, MPG, PED, PS, respectively [15-21]. 100 titles were continuously randomly selected from each journal, for the period of the recent five years 2013 - 2018 .

\section{Methodology}

The selected article titles were analyzed in order to determine their characteristic features: a. the number of words per title; $b$. the number of characters per word and title; c. word classes of the constituent verbal content; $d$. punctuation marks; e. the number of geographical names per title, and their geographical scope. Statistical data - mean, maximum, minimum values, deviation (dev.), standard deviation (st.dev.) - were obtained with the help of Microsoft Excel 2007.

\section{Results}

Words per title. The average number of words per title varied in the range of 13-16, with the longest titles belonging to MPG and JPG (15 words). Maximum and minimum values demonstrated wider variation: the longest titles occurred in JUOGR (34 words) and MPG (33 words). The shortest titles were discovered in JUOGR (3 words) and JPG (4 words):

(1) Characterization of fine-scale rock structure and differences in mechanical properties in tight oil reservoirs: An evaluation at the scale of elementary lithological components combining photographic and X-ray computed tomographic imaging, profile-permeability and microhardness testing (JUOGR) - 34 words

(2) Major factors affecting the closure of marine carbonate caprock and their quantitative evaluation: A case study of Ordovician rocks on the northern slope of the Tazhong uplift in the Tarim Basin, western China (MPG) - 33 words 
(3) Composition and distribution of NSO compounds in two different shales at the early maturity stage characterized by negative ion electrospray ionization coupled with Fourier transform ion cyclotron resonance mass spectrometry (PS) 30 words

(4) Multi-zone stimulation technology (JUOGR) - 3 words

(5) HYDROCARBON POTENTIAL IN JORDAN (JPG) - 4 words

(6) Experimental evaluation of fracture stabilizers (PED) - 5 words

PG and JPG showed the lowest standard deviation values: 4.27 and 4.28, respectively, implying stability in the lengths of their titles, as opposed to MPG (5.92) and JUOGR (4.86). MPG and JOUGR also demonstrated the largest difference between maximum and minimum values: 31 and 26 words, respectively (Tb. 1).

Table 1 / Таблица 1

The length of article titles, in words / Длина заголовков статей, в словах

\begin{tabular}{lllllllll}
\hline Journals, abbr.: & MPG & JPG & PS & PG & JUOGR & JPSE & PED & Aver. \\
\hline Mean & 16 & 16 & 15 & 15 & 14 & 13 & 13 & 15 \\
\hline Max & 33 & 27 & 30 & 28 & 34 & 26 & 26 & 29 \\
\hline Min & 7 & 4 & 7 & 7 & 3 & 6 & 5 & 6 \\
\hline Dev. & 35.06 & 18.34 & 23.33 & 18.19 & 23.61 & 19.61 & 21.86 & 22.86 \\
\hline St. dev. & 5.92 & 4.28 & 4.83 & 4.27 & 4.86 & 4.43 & 4.68 & 4.75 \\
\hline Max-Min & 26 & 23 & 23 & 21 & 31 & 20 & 21 & 24 \\
\hline
\end{tabular}

The titles were compared for statistically relevant difference in their length with the help of the Student's t-test. Each sample set was compared to all other sets, for example, JPSE vs. PED, JPSE vs. JUOGR, JPSE vs. MPG, JPSE vs. PG, JPSE vs. JPG, JPSE vs. PS. The results are presented in Tb. 2, where cells in the bottom left remained blank, as the values, being paired, duplicate those in the upper right part of the table.

Table 2 / Таблица 2

The results of Student's t-test / Результаты теста по критерию Стьютента

\begin{tabular}{|c|c|c|c|c|c|c|c|}
\hline Journals & PED & JPSE & JUOGR & MPG & $P G$ & JPG & PS \\
\hline PED & 1 & 1.2 (irr) & 1.3 (irr) & $4.6(r)$ & $3.3(r)$ & $4.5(r)$ & 2.6 (amb) \\
\hline JPSE & & 1 & 0.8 (irr) & $4.2(r)$ & $2.8(r)$ & $4(r)$ & $2.1(\mathrm{amb})$ \\
\hline JUOGR & & & 1 & $3.4(r)$ & 1.9 (irr) & $3(r)$ & 1.2 (irr) \\
\hline MPG & & & & 1 & 1.9 (irr) & 0.9 (irr) & $2.3(\mathrm{amb})$ \\
\hline$P G$ & & & & & 1 & 1.2 (irr) & 0.6 (irr) \\
\hline JPG & & & & & & 1 & 1.7 (irr) \\
\hline PS & & & & & & & 1 \\
\hline
\end{tabular}

$\mathrm{p} \leq 0.05$, critical value $\mathrm{t}=1.97 ; \mathrm{p} \leq 0.01$, critical value $\mathrm{t} .=2.61$

(r) - statistically relevant results; (irr) — statistically irrelevant results; (amb) ambiguous results 
According to the obtained results, titles from MPG, PG and JPG tended to be consistently longer than those from PED, JPSE, and JUOGR (except for PG), as their differences occurred to be statistically relevant. These differences can be arguably explained by the subject areas of the journals: MPG, PG and JPG specialize in geology, exploration and prospecting, which implicate mentioning geographical names.

b. Characters per word and title. The average length of one word in article titles equaled 7 characters (letters) (Tb. 3). These results were gained as a result of dividing the number of symbols per title by the number of words per title. The lowest standard deviation was observed in PED (0.75), which implied consistency in the length of its words. JUOGR was characterized by the highest deviation (1.04). The only journal with 8 symbols per word was JPSE, which can be explained by the presence of a variety of multisyllabic technical, chemical terms.

Table 3 / Таблица 3

The length of article titles, in characters / Длина заголовков статей, в символах

\begin{tabular}{lllllllll}
\hline Journals: & MPG & JPG & PS & PG & JUOGR & JPSE & PED & Aver. \\
\hline Per title & 120 & 115 & 107 & 109 & 102 & 101 & 94 & 107 \\
\hline Dev. & 1637.54 & 1038.12 & 1004.84 & 961.65 & 1397.29 & 990.76 & 923.47 & 1136.24 \\
\hline St. dev. & 40.47 & 32.22 & 31.7 & 31.01 & 37.38 & 31.48 & 30.39 & 33.52 \\
\hline Per word & 7 & 7 & 7 & 7 & 7 & 8 & 7 & 7 \\
\hline Dev. & 0.89 & 0.87 & 0.79 & 0.73 & 1.09 & 0.78 & 0.57 & 0.82 \\
\hline St. dev. & 0.94 & 0.93 & 0.89 & 0.86 & 1.04 & 0.89 & 0.75 & 0.9 \\
\hline
\end{tabular}

Polysyllabic words in JPSE can be divided into two broad categories: firstly, terms, related to petroleum engineering; secondly, to general scientific research:

(7) annealing, hydrolyzed, nanoparticle, polyacrylamides, triethanolamine, fluorescence, imbibitions, naphthenic, radiofrequency, viscoelastic, fracability, metaheuristic, orthosilicate, rheological, volumetric, geochemical, phosphonate, spectrophotometry, wettability.

(8) accumulations, characterization, connectionist, evaluation, inhibition, recognition, application, contribution, experimental, methodology, redevelopment, breakthrough, decomposition, fundamentals, optimization, revitalizing, characteristics, determination, heterogeneity, parametric, stimulation.

In addition, JPSE's titles were characterized by compound modifiers, consisting of 2-3 words, joined with a hyphen, which were counted as one word:

(9) petro-physical, fracture-to-fracture, pseudo-three-dimensional, alkalinebased, oil-base-mud-filtrate, limited-entry, multi-cluster, highly-deviated, hexatriethanolamine, probe-type formation-tester, solvent-assisted, ammoniumcontaining, nanoparticle-surfactant-polymerover

c. Word classes. Preliminary analysis showed that words in the article titles could be divided into the following classes: nouns, adjectives, gerunds, infinitives, verbs (V-s), numbers, abbreviations, and function words (FW) as a collective subgroup, which included articles, pronouns, prepositions, and conjunctions. The total number of words per 100 titles varied from 1300 (PED) to 1647 (MPG) (Tb. 4). 
Word classes in the article titles / Части речи в заголовках статей

\begin{tabular}{|c|c|c|c|c|c|c|c|c|c|}
\hline PED & Nouns & FW & Adj. & Ger. & Abbr. & Inf. & Numb. & Adv. & V-s \\
\hline Mean, per title & 7 & 3 & 2 & 2 & 1 & 1 & 1 & - & - \\
\hline Dev. & 6.78 & 3.16 & 1.42 & 0.68 & 0.06 & - & - & - & - \\
\hline St. dev. & 2.6 & 1.78 & 1.19 & 0.83 & 0.24 & - & - & - & - \\
\hline Total Sum (1300) & 670 & 342 & 220 & 45 & 19 & 2 & 2 & - & - \\
\hline Per cent & $52 \%$ & $26 \%$ & $17 \%$ & $3 \%$ & $1 \%$ & $0 \%$ & $0 \%$ & - & - \\
\hline JPSE & Nouns & $\mathrm{FW}$ & Adj. & Ger. & Abbr. & Inf. & Numb. & Adv. & V-s \\
\hline Mean, per title & 6 & 4 & 3 & 1 & 1 & 1 & 1 & 1 & 1 \\
\hline Dev. & 5.82 & 3.56 & 2.38 & 0.42 & 0.24 & 0.11 & - & 0.00 & - \\
\hline St. dev. & 2.41 & 1.89 & 1.54 & 0.65 & 0.49 & 0.33 & - & 0.00 & - \\
\hline Total Sum (1338) & 641 & 360 & 233 & 71 & 19 & 10 & 1 & 2 & 1 \\
\hline Per cent & $48 \%$ & $27 \%$ & $17 \%$ & $5 \%$ & $1 \%$ & $1 \%$ & $0 \%$ & $0 \%$ & $0 \%$ \\
\hline JUOGR & Nouns & $\mathrm{FW}$ & Adj. & Ger. & Abbr. & Inf. & Numb. & Adv. & V-s \\
\hline Mean, per title & 7 & 4 & 3 & 1 & 1 & 1 & 1 & 1 & 2 \\
\hline Dev. & 5.75 & 3.29 & 2.23 & 0.38 & 0.54 & - & - & 0.2 & 0.5 \\
\hline St. dev. & 2.4 & 1.81 & 1.49 & 0.62 & 0.73 & - & - & 0.45 & 0.71 \\
\hline Total Sum (1404) & 688 & 384 & 223 & 69 & 24 & 5 & 2 & 6 & 3 \\
\hline Per cent & $49 \%$ & $27 \%$ & $16 \%$ & $5 \%$ & $2 \%$ & $0 \%$ & $0 \%$ & $0 \%$ & $0 \%$ \\
\hline MPG & Nouns & $\mathrm{FW}$ & Adj. & Ger. & Abbr. & Inf. & Numb. & Adv. & V-s \\
\hline Mean, per title & 9 & 5 & 3 & 1 & 1 & 1 & 1 & 1 & 2 \\
\hline Dev. & 11.77 & 4.72 & 2.25 & 0.28 & 0.29 & - & 0.33 & - & - \\
\hline St. dev. & 3.43 & 2.17 & 1.5 & 0.53 & 0.54 & - & 0.58 & - & - \\
\hline Total Sum (1647) & 853 & 464 & 253 & 46 & 23 & 1 & 4 & 1 & 2 \\
\hline Per cent & $52 \%$ & $28 \%$ & $15 \%$ & $3 \%$ & $1 \%$ & $0 \%$ & $0 \%$ & $0 \%$ & $0 \%$ \\
\hline$P G$ & Nouns & FW & Adj. & Ger. & Abbr. & Inf. & Numb. & Adv. & V-s \\
\hline Mean, per title & 7 & 4 & 3 & 1 & 1 & 1 & 1 & 1 & 2 \\
\hline Dev & 7.34 & 3.6 & 2.56 & 0.33 & 0.00 & 0.00 & 0.17 & 0.00 & 0.25 \\
\hline St. dev. & 2.71 & 1.9 & 1.6 & 0.57 & 0.00 & 0.00 & 0.41 & 0.00 & 0.5 \\
\hline Sum (1510) & 701 & 444 & 254 & 60 & 27 & 7 & 7 & 3 & 7 \\
\hline Per cent & $46 \%$ & $29 \%$ & $17 \%$ & $4 \%$ & $2 \%$ & $0 \%$ & $0 \%$ & $0 \%$ & $0 \%$ \\
\hline$J P G$ & Nouns & $\mathrm{FW}$ & Adj. & Ger. & Abbr. & Inf. & Numb. & Adv. & V-s \\
\hline Mean, per title & 8 & 4 & 3 & 1 & 1 & 1 & 1 & 1 & 1 \\
\hline Dev & 6.32 & 2.77 & 2.91 & 0.25 & 0.06 & - & 0.00 & 0.00 & - \\
\hline St. dev. & 2.51 & 1.66 & 1.70 & 0.5 & 0.25 & - & 0.00 & 0.00 & - \\
\hline Sum (1581) & 828 & 404 & 283 & 26 & 32 & 1 & 3 & 3 & 1 \\
\hline Per cent & $52 \%$ & $26 \%$ & $18 \%$ & $2 \%$ & $2 \%$ & $0 \%$ & $0 \%$ & $0 \%$ & $0 \%$ \\
\hline $\mathrm{PS}$ & Nouns & FW & Adj. & Ger. & Abbr. & Inf. & Numb. & Adv. & $\mathrm{V}-\mathrm{s}$ \\
\hline Mean, per title & 7 & 4 & 3 & 1 & 1 & 1 & 1 & 1 & 2 \\
\hline Dev & 7.97 & 4.02 & 1.61 & 0.39 & 0.69 & 0.00 & 0.2 & 0.00 & 0.5 \\
\hline St. dev. & 2.82 & 2.01 & 1.27 & 0.62 & 0.83 & 0.00 & 0.45 & 0.00 & 0.71 \\
\hline Sum (1474) & 722 & 405 & 241 & 54 & 34 & 4 & 6 & 5 & 3 \\
\hline Per cent & $49 \%$ & $27 \%$ & $16 \%$ & $4 \%$ & $2 \%$ & $0 \%$ & $0 \%$ & $0 \%$ & $0 \%$ \\
\hline
\end{tabular}


According to the gained results, nouns were the most numerous word class, exceeding FW by 1.8, on average; more specifically, by 1.6 (PG), 1.8 (JPSE, JUOGR, PS), 1.9 (MPG), 2 (JPG, PED). Overall, there were 6-9 nouns per title, 7 nouns, on average. Adjectives were less abundant than FW — averagely, by 1.6. The variation fell within the range $1.4(\mathrm{JPG})-1.9(\mathrm{MPG})$. As an average value, there were 3 adjectives per title. Gerunds, present in $2-5 \%$ of titles, were more frequent than infinitives. Infinitives, numbers and verbs hardly exceeded $1 \%$ (Tb. 4). It should be mentioned here that the presence of verbs indicated titles in the form of complete 'subjectpredicate' sentences:

(10) Unconventional oil and gas resource development - Let's do it right (JUOGR)

(11) Hybrid connectionist model determines CO2-oil swelling factor (PS)

(12) Use of community mobile phone big location data to recognize unusual patterns close to a pipeline which may indicate unauthorized activities and possible risk of damage (PS)

Abbreviations were observed in all journals (titles), comprising $1-2 \%$ of the total quantity of words. They included cardinal directions: $N W, S W, N E, S E$; and technical terms, e.g. NMR - nuclear magnetic resonance, SVM - support vector machine, EOR - enhanced oil recovery, BHP — bottom hole pressure, THAI - toe-toheel air injection (a process for oil recovery and upgrading in situ in the reservoir), $\mathrm{SAGD}$ - steam assisted gravity drainage, $\mathrm{Al}_{2} \mathrm{O}_{3}$ - aluminium oxide, $\mathrm{CO}_{2}$ - carbon dioxide, VES - viscoelastic surfactants, TOC — total organic carbon, MinC(\%) mineral carbon content parameter, WAG - water-alternating-gas, Re-Os - rhenium-osmium, PMDA - pyromellitic dianhydride, PAN — polyacrylonitrile, PVA poly(vinyl alcohol), USY - ultrastable Y zeolite, DME — dimethyl ether, TBAF tetra-n-butylammonium fluoride, NSO — nitrogen, sulfur and oxygen.

(13) Simulation and analysis of wormhole propagation by VES acid in carbonate acidizing (JPSE)

(14) Evaluation of the EOR potential of gas and water injection in shale oil reservoirs (JUOGR)

(15) Fabrication of high-performance PVA/PAN composite pervaporation membranes crosslinked by PMDA for wastewater desalination (PS)

d. Punctuation marks. Generally, 672 from 700, or 96\%, article titles contained punctuation marks (Tb. 5). Some titles contained a few marks, e.g. a colon, two or three commas, and a dash. Others were free of punctuation marks at all:

(16) THE LOWER CAMBRIAN NIUTITANG FORMATION AT YANGTIAO (GUIZHOU, SW CHINA): ORGANIC MATTER ENRICHMENT, SOURCE ROCK POTENTIAL, AND HYDROTHERMAL INFLUENCES (JPG) - 19 words: bracket, commas, colon.

(17) Composition and distribution of NSO compounds in two different shales at the early maturity stage characterized by negative ion electrospray ionization coupled with Fourier transform ion cyclotron resonance mass spectrometry (PS) - 30 words: no punctuation marks.

The most numerous marks were hyphen, present in $37 \%$ per 100 titles, on average; followed by comma (25\%) and colon (23\%). Other punctuation marks were by 
far less abundant: $5 \%$ and lower (Tb. 5). The titles with multiple punctuation marks belonged to JPG (153), MPG (120) and PG (101) — those journals which contained most of geographical names (see below).

Table 5 / Таблица 5

The quantity of punctuation marks per 100 titles /

Количество знаков пунктуации на 100 заголовков

\begin{tabular}{lllllllllll}
\hline Journals: & JPG & MPG & PG & JUOGR & PS & JPSE & PED & Mean & Sum \\
\hline 1 & Hyphen & 35 & 39 & 40 & 37 & 34 & 39 & 34 & 37 & 258 \\
\hline 2 & Comma & 66 & 32 & 20 & 13 & 15 & 6 & 24 & 25 & 176 \\
\hline 3 & Colon & 36 & 36 & 32 & 16 & 16 & 13 & 10 & 23 & 159 \\
\hline 4 & Bracket & 10 & 6 & 6 & 4 & 6 & 3 & 0 & 5 & 35 \\
\hline 5 & Dash & 4 & 4 & 2 & 9 & 0 & 5 & 0 & 5 & 24 \\
\hline 6 & Slash & 0 & 1 & 0 & 0 & 3 & 4 & 0 & 1 & 8 \\
\hline 7 & Inverted commas & 2 & 1 & 0 & 0 & 0 & 0 & 2 & 1 & 2 \\
\hline 8 & Dot & 0 & 0 & 0 & 1 & 0 & 1 & 0 & 0 & 5 \\
\hline 9 & Plus & 0 & 0 & 0 & 1 & 2 & 0 & 0 & 0 & 3 \\
\hline 10 & Per cent & 0 & 1 & 0 & 0 & 0 & 0 & 0 & 0 & 1 \\
\hline 11 & Semicolon & 0 & 0 & 1 & 0 & 0 & 0 & 0 & 0 & 1 \\
\hline & Total & 153 & 120 & 101 & 81 & 76 & 71 & 70 & 96 & 672 \\
\hline
\end{tabular}

Commas mainly served for delimiting geographical names; therefore the journals with the most numerous geographical places contained the highest number of commas. Brackets and commas could be mutually replaceable for specifying geographical locations:

(18) Application of charging effects in evaluating storage space of tight reservoirs: A case study from Permian Lucaogou Formation in Jimusar sag, Junggar Basin, NW China (PED)

(19) Integrated analysis of geoelectric and surface geochemical data for exploration of subsurface hydrocarbon accumulations (Carpathian Foredeep, SE Poland) (JPSE)

Colons in article titles were used for the introduction of purposes of research and geographical or engineering objects. Key words after the colon were as follows: a case, case study, study, analysis, investigation, an example, overview, insights, implications, opportunities, possibilities, challenges, constraints, limitations, modelling, method, approach, perspective, potential, procedure, application, core-sampling, understanding, determination, corrections, prediction, characterization, significance, impact, agenda, maps, workflow, problem formulation, evaluation, influence, oil accumulation, geochemistry, geochronology, biodegradation, evolution, feedstock, development, verification, interpretation, factors, effects, processes, prospects, systems, a template, model, status, interplay.

(20) Quantitative estimation of petroleum prospect outcome probabilities: an overview of procedures (MPG) 
(21) Gas production from a cold, stratigraphically-bounded gas hydrate deposit at the Mount Elbert Gas Hydrate Stratigraphic Test Well, Alaska North Slope: Implications of uncertainties (MPG)

(22) Examining fault architecture and strain distribution using geospatial and geomechanical modelling: An example from the Qaidam basin, NE Tibet (MPG)

(23) Major factors affecting the closure of marine carbonate caprock and their quantitative evaluation: A case study of Ordovician rocks on the northern slope of the Tazhong uplift in the Tarim Basin, western China (MPG)

Colons and dashes were sometimes interchangeable for determining types of research in articles:

(24) Synergistic effect of like and opposite charged nanoparticle and surfactant on foam stability and mobility in the absence and presence of hydrocarbon: A comparative study (JPSE)

(25) Reservoir prediction of deep-water turbidite sandstones with seismic lithofacies control - A case study in the C block of lower Congo basin (MPG)

The presence of dots did not transform titles into complete subject-predicate sentences:

(26) Organic bases, carbon dioxide and naphthenic acids interactions. Effect on the stability of petroleum crude oil in water emulsions (JPSE)

Slashes denoted alternative or correlated technical terms:

(27) A radiofrequency/microwave heating method for thermal heavy oil recovery based on a novel tight-shell conceptual design (JPSE)

Hyphens fulfilled the functions of joining related concepts ('oil-gas'), compound modifiers ('micro-nano'), or syntactic merge ('above-source'). They sometimes showed a process of converting one substance into another ('oil-to-gas'): (PED)

(28) Oil-gas exploration potential for above-source plays in Nanpu sag

(29) Potential application of functional micro-nano structures in petroleum (PED)

(30) THE EFFECTS OF HIGH PRESSURE ON OIL-TO-GAS CRACKING DURING LABORATORY SIMULATION EXPERIMENTS (JPG)

Inverted commas served for introducing phrases of neological character:

(31) The "fracture-controlled reserves" based stimulation technology for unconventional oil and gas reservoirs (PED)

(32) Estimated location of the seafloor sources of marine natural oil seeps from sea surface outbreaks: A new "source path procedure" applied to the northern Gulf of Mexico (MPG)

e. Questions. Among 700 titles, only eleven of them (2\%) from PG, JPG and MPG had the syntactic form of a question:

(33) Why are there no Messinian evaporites in the Black Sea? (PG)

(34) ARE SHOAL RESERVOIRS DISCRETE BODIES? A COQUINA SHOAL OUTCROP ANALOGUE FROM THE MID TRIASSIC UPPER MUSCHELKALK, SW GERMANY (JPG)

(35) Lateral transfer: a source of additional overpressure? (MPG) 
f. Geographical names. The amount of lexical content, denoting geographical places, constituted about $30 \%$ of article titles, on average (Tb. 6). The longest average values were typical of JPG (39\%), PED (37\%) and MPG (33\%).

Table 6 / Таблица 6

The length of geography-related words / Длина географических обозначений

\begin{tabular}{lllllllll}
\hline Journals, abbr. & MPG & JPG & PS & PG & JUOGR & JPSE & PED & Aver. \\
\hline Mean & $33 \%$ & $39 \%$ & $27 \%$ & $27 \%$ & $24 \%$ & $26 \%$ & $37 \%$ & $30 \%$ \\
\hline Max & $64 \%$ & $76 \%$ & $71 \%$ & $67 \%$ & $50 \%$ & $33 \%$ & $80 \%$ & $63 \%$ \\
\hline Min & $7 \%$ & $6 \%$ & $4 \%$ & $7 \%$ & $8 \%$ & $21 \%$ & $6 \%$ & $8 \%$ \\
\hline Dev. & 0.02 & 0.03 & 0.04 & 0.01 & 0.02 & 0.002 & 0.04 & 0.02 \\
\hline St. dev. & 0.14 & 0.16 & 0.2 & 0.12 & 0.13 & 0.045 & 0.21 & 0.14 \\
\hline
\end{tabular}

The maximum values varied in the range from 33\% (JPSE) to $80 \%$ (PED); the minimum values - from $4 \%$ (PS) to $21 \%$ (JPSE):

(36) Overpressure reservoirs of the Huangliu Formation of the Dongfang area, Yinggehai Basin, South China Sea (PED) - 80\%, maximum

(37) Study of the impacts of upstream natural gas market reform in China on infrastructure deployment and social welfare using an SVM-based rolling horizon stochastic game analysis (PS) - 4\%, minimum

There are petroleum reservoirs around the world, and there has been exponential growth in proved petroleum reserves over the last two decades, despite a prevailing opinion about near depletion of oil and gas deposits [11. P. 267]. However, the regional distribution of crude oil reserves is very uneven. About $62 \%$ of global reserves are in the Middle East, about $13 \%$ in North and South America, and about $10 \%$ in the Commonwealth of Independent States countries [12].

According to the obtained results, 327 from 700 titles, or 47\%, contained geographical names (Tb. 7). The highest quantity of titles with geographical names belonged to JPG - 95\%. Almost identical number $64 \%$ and $63 \%$ characterized two journals: MPG and PG, correspondently. The journal with the lowest quantity $7 \%$ occurred to be JPSE [13].

The overall data showed that the geographical places described in the samples of article titles embraced Asia, Europe, Middle East, Africa, North America, South America and Australia; in other words, almost all continents (Tb. 7). MPG and PG included article titles with the widest geographical scope (8 regions each). The fewest regions, only 2, were presented in PED.

Relative data, given in square brackets, testify that JPG mainly included geographical places from Middle East (25\%), Africa (19\%) and Europe (34\%). Article titles, containing those from China and Europe, were the most numerous in MPG. Reservoirs from Africa (22\%) and Europe (27\%) made up the largest part of titles in PG. PED and PS's titles were mostly characterized by Chinese reserves - $98 \%$ and $67 \%$, respectively. JOUGR contained $57 \%$ of American basins, and JPSE - American $(29 \%)$ and Chinese $(29 \%)$, equally. 
Table 7 / Таблица 7

Consolidated geographical scope of petroleum fields in article titles, \% /
Сводные географические данные о нефтяных месторождениях в заголовках статей, \%

\begin{tabular}{llllllll}
\hline Journals: & JPG & MPG & PG & PED & PS & JUOGR & JPSE \\
\% of geogr. names & 95 & 64 & 63 & 41 & 29 & 28 & 7 \\
\hline Asia & $14[15]$ & $4[6]$ & $10[16]$ & - & $5[17]$ & $8[29]$ & - \\
\hline China & - & $26[41]$ & - & $40[98]$ & $18[67]$ & - & $2[29]$ \\
\hline Middle East & $24[25]$ & $5[8]$ & - & $1[2]$ & $1[3]$ & - & - \\
\hline Africa & $18[19]$ & $3[5]$ & $14[22]$ & - & $1[3]$ & $2[7]$ & $1[14]$ \\
\hline Europe & $32[34]$ & $14[22]$ & $17[27]$ & - & - & - & $1[14]$ \\
\hline The UK & - & - & $6[10]$ & - & - & - & - \\
\hline Nordic Region & - & - & $10[16]$ & - & $2[7]$ & - & - \\
\hline North America & - & $6[9]$ & $1[2]$ & - & $1[3]$ & $16[57]$ & $2[29]$ \\
\hline South America & $5[5]$ & $2[3]$ & $4[6]$ & - & $1[3]$ & - & - \\
\hline Australia & $2[2]$ & $4[6]$ & $1[2]$ & - & - & $2[7]$ & $1[14]$ \\
\hline (Number of regions) & $(6)$ & $(8)$ & $(8)$ & $(2)$ & $(7)$ & $(4)$ & $(5)$ \\
\hline
\end{tabular}

The aggregate quantity of mentioned geographical names in titles largely reflects the amounts of petroleum, depicted in Fig. 1 [14]: China, 235; North America, 100; Europe, 97; Asia, 83; Africa, 70; Middle East, 38; Australia, 31; Nordic Region, 23; South America, 17; and the UK, 10.

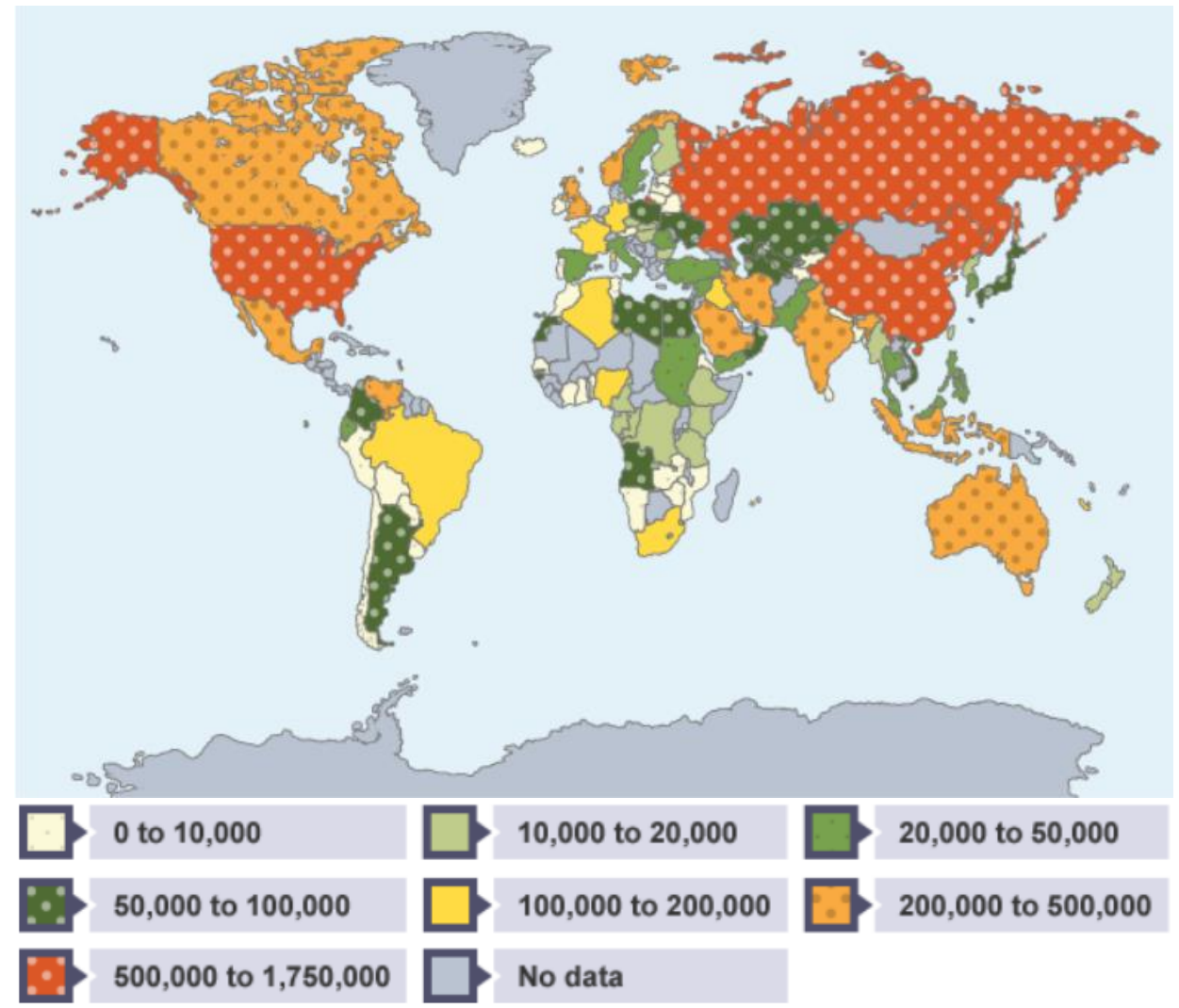

Fig. 1. The amount of oil available in different countries (thousand tons of oil equivalent)/

Рис. 1. Количество нефтяных запасов в различных странах (тысяча тонн, в нефтяном эквиваленте) 


\section{Conclusion}

To summarize, research article titles on petroleum science were characterized by 15 words (107 characters) per title, on average; though actual numbers varied within a wide range: 3-34 words per title. Certain journals had consistently shorter titles (PED 94 char., JPSE 101 char., and JUOGR 102 char., on average). Words were averagely 7 characters long (JPSE -8 char.), since they included complex technical terms and compound hyphened modifiers.

The article titles were characterized by the prevalent number of nouns. They constituted half of all other word classes, thus preserving the nominative nature of titles. Full subject-predicate sentences were exceptionally rare, not exceeding $2 \%$; and most of them were interrogative. Function words were half as many as nouns. Adjectives were 3 times less numerous than nouns, on average. The gerund as a non-finite form of the verb was a more frequently occurring word class $(2-5 \%)$ than the infinitive. Adverbs, verbs, infinitives, abbreviations, and numbers did not exceed $1 \%$ per 100 titles. Abbreviations included cardinal directions and technical terms.

Punctuation marks were present in $96 \%$ of the titles, in general. Some of them were functionally interchangeable. Hyphens, commas and colons were the most common. Brackets and dashes were equally rare. Slashes, inverted commas, dots, pluses, per cent, and semicolons hardly ever occurred.

Geographical names were present in almost half of the analyzed article titles. They often consisted of three parts: 1) the names of reservoirs, basins, formations; 2) regions, areas, territories of petroleum occurrence; and 3) countries. The length of geographical names was $30 \%$ on average, varying between $4 \%$ and $80 \%$. Three journals had above-average values of geographical names' length: JPG (39\%), PED $(37 \%)$ and MPG $(33 \%)$.

The titles from three journals embraced wider geographical coverage: JPG 95\%, MPG 64\%, and PG 63\%. Titles from JPSE, on the contrary, contained the lowest number of geographical names, only $7 \%$. Chinese geographical places were prevalent in article titles from two journals: PED, and PS.

Generally, the quantity of article titles, containing geographical places, corresponded to the amounts of petroleum reserves in those areas. The higher the resource potential, the more article titles were devoted to those petroleum reservoirs.

Considering all the above mentioned, research article titles on petroleum science were characterized by significant average length, explained by the presence of a substantial quantity of explicit geographical names which implied extensive use of nouns and punctuation marks for specifying locations of reservoirs. In addition, multisyllabic technical terms, denoting chemical substances, physical phenomena, industry-related equipment and processes, also contributed to extended length of article titles and the average length of the constituent words. It can be assumed that long article titles on petroleum science result from specifying certain technical and geological parameters. 


\section{References}

1. Ryabtseva, N.K. (2018). Academic Paper Titles and Their Dominating Patterns: a RussianEnglish Perspective. Science Journal of Volgograd State University. Linguistics, 17(2), 3343. (In Russ.).

2. Filyasova, Yu.A. (2018). News Headlines: A Contrastive Linguistic Analysis In Proc. of the $5^{\text {th }}$ International Multidisciplinary Scientific Conference on Social Sciences and Arts SGEM 2018, 19-21 March, 2018, 5(3.1). pp. 333-344. (In Russ.).

3. Filyasova, Yu.A., Selenkov, A.A. \& Evseeva, A.A. (2018). BBC News Headlines' Characteristics In Dolzhnikova A.V., Barabash V.V. (eds.) Proc. of the $2^{\text {nd }}$ International Scientific Practical Conference "Language and Speech in the Internet: Personality, Society, Communication, and Culture”, 29-30 March 2018, 2. Moscow: RUDN. pp. 335-342. (In Russ.).

4. Filyasova, Yu.A. (2019). Effectiveness vs. efficiency: An analysis of valency and collocability in a technical context. RUDN Journal of Language Studies, Semiotics and Semantics, $10(1), 187-196$.

5. Filyasova, Yu.A. (2019). Linguistic characteristics of research article titles (evidence from the Journal of Petroleum Geology) In E.A. Gorbasko (ed.) Modern development of Russia through the prism of scientific research. Saint-Petersburg: SPSUE. pp. 564-567. (In Russ.).

6. Fox, C. \& Burns, C. (2015). The relationship between manuscript title structure and success: Editorial decisions and citation performance for an ecological journal. Ecology and Evolution, 5(10), 1970-1980.

7. Soler, V. (2007). Writing titles in science: An exploratory study. English for Specific Purposes, 26(1), 90-102.

8. Letchford, A., Moat, H. \& Preis, T. (2015). The advantage of short paper titles. Royal Society Open Science, 2(8).

9. Jamali, H. \& Nikzad, M. (2011). Article title type and its relation with the number of downloads and citations. Scientometrics, 88(2), 653-661.

10. Bramoulle, Y. \& Ductor, L. (2018). Title length. Journal of Economic Behavior and Organization, 150, 311-324.

11. Fedchenko, A.A. \& Iseeva, L.I. (2013). Trends in Production of Oil and Reproduction Mineral Base Oil in Russia and in the World. Journal of Mining Institute, 205, 266-270.

12. Rempel, H. (2006). Geographical Distribution of Oil and Natural Gas Deposits - Different Means of Transportation to the Consumption Centers In 1st Pipeline Technology Conference, April, 25, 2006. Hannover.

13. Filyasova, Yu.A., Makhno, D.A. \& Shubin, A.V. (2018). Geographical Scope of Petroleum Reserves in Research Article Titles (A Sampling Analysis) In 18th International Multidisciplinary Scientific GeoConference SGEM 2018, Section: Oil and Gas Exploration, SGEM2018 Conference Proceedings, 3-6 December, 2018, 18 (1.5). pp. 109-118.

14. Global distribution of energy resources. Fossil Fuels. Oil. BBC. URL: https://www.bbc.com/ education/guides/z3pppv4/revision/3 (accessed: 24.17.2018).

\section{Журналы / Journals}

15. Journal of Petroleum Geology. URL: https://onlinelibrary.wiley.com/journal/17475457 (accessed 5 July 2018)

16. Journal of Petroleum Science and Engineering. URL: https://www.journals.elsevier.com/ journal-of-petroleum-science-and-engineering (accessed: 12 July 2018).

17. Journal of Unconventional Oil and Gas Resources. URL: https://www.journals.elsevier.com/ journal-of-unconventional-oil-and-gas-resources (accessed: 10 July 2018).

18. Marine and Petroleum Geology. URL: https://www.journals.elsevier.com/marine-andpetroleumgeology (accessed: 15 July 2018). 
19. Petroleum Exploration and Development. URL: https://www.journals.elsevier.com/ petroleum-exploration-and-development (accessed: 1 July 2018).

20. Petroleum Geoscience. URL: http://pg.lyellcollection.org/ (accessed: 8 July 2018).

21. Petroleum Science. URL: https://www.springer.com/earth+sciences+and+geography/ mineralogy+\%26+sedimentology/journal/12182 (accessed: 7 July 2018).

\section{Библиографический список}

1. Рябцева Н.К. Название как доминантный компонент научного текста: русскоанглийские межъязыковые «несоответствия» // Вестник Волгоградского государственного университета. Серия 2, Языкознание. 2018. Т. 17. по 2. С. 33-43.

2. Филясова Ю.А. Заголовки новостей: Сопоставительный лингвистический анализ // Мат. 5-й междунар. междисц. науч. конф. по соц. наукам и иск-ву. Вена. 2018. Т. 5(3.1). C. $333-344$.

3. Филясова Ю.А., Селенков А.А., Евсеева А.А. Характеристики заголовков статей БиБиСи // Язык и речь в Интернете: личность, общество, коммуникация, культура: сб. ст. II Междунар. науч.-практ. конф. Т. 2. / Под общ. ред. А.В. Должиковой, В.В. Барабаша. М.: Издво РУДН, 2018. С. 335-342.

4. Филясова Ю.А. Effectiveness vs. efficiency: анализ валентности и сочетаемости в техническом контексте // Вестник Российского университета дружбы народов. Серия: Теория языка. Семиотика. Семантика. 2019. Т.10. по 1. С. 187-196.

5. Филясова Ю.А. Лингвистические характеристики заголовков научных статей (на материале "The Journal of Petroleum Geology") // Современное развитие России через призму научных исследований / Под ред. Е.А. Горбашко. СПб.: Изд-во СПбГЭУ, 2019. C. $564-567$.

6. Фокс Ч., Бёрнс Ш. Соотношение между структурой заголовка научной статьи и ее известностью: Редакторские решения и количество цитирований, на материале журнала по экологии // Экология и эволюция, 2015. по 5(10). С. 1970-1980.

7. Солер $B$. Написание научных заголовков: исследовательский анализ // Английский для специальных целей. 2007. по 26(1). С. 90-102.

8. Лечфорд A., Моут X., Прайс T. Преимущество кратких научных заголовков // Открытая наука Королевского общества. 2015. по 2(8).

9. Джамали $X .$, Никзад M. Вид заголовка статьи и его соотношение с количеством скачиваний и цитирований // Наукометрика. 2011. nо 88(2). С. 653-661.

10. Брамуль Я., Дуктор Л. Длина заголовка // Журнал экономического поведения и организации. 2018. nо 150. С. $311-324$.

11. Федченко А.А., Исеева Л.И. Тенденции изменения добычи и воспроизводства минерально-сырьевой базы нефти в России и мире // Записки Горного института. 2013. no 205. C. $266-270$.

12. Ремпель Г. Географическое распределение запасов нефти и природного газа - различные способы транспортировки к центрам энергопотребления // 1-ая Конференция по технологиям транспортировки трубопроводным транспортом, Ганновер, 25 апреля 2006.

13. Филясова Ю.А., Махно Д.А., Шубин А.В. Географический охват запасов нефти в названиях научных статей (выборочный анализ) // Материалы 18 Международной мультидисциплинарной научной Гео-конференции SGEM 2018, Секция: Разведка нефти и газа. 3-6 дек. 2018. nо 18 (1.5). С. 109-118.

14. Глобальное распределение энергоресурсов. Полезные ископаемые. Нефть. // БиБиСи. URL: https://www.bbc.com/education/guides/z3pppv4/revision/3 (дата обращения: 24.17.2018). 


\section{Сведения об авторе:}

Филясова Юлия Анатольевна, кандидат филологических наук, доцент кафедры педагогики, психологии и переводоведения Санкт-Петербургского университета технологий управления и экономики (Россия); научные интересы: лингвистика, фонетика, деловой английский язык, медиадискурс, технический перевод, педагогика; e-mail: phill.yield@gmail.com. eLibrary SPIN-код: 9503-8000

\section{Information about the author:}

Yulia Filyasova, Candidate of Philological Sciences, Associate Professor of the Department of Pedagogy, Psychology and Translation Studies, Saint-Petersburg University of Management Technologies and Economics (Russia); scientific interests: linguistics, phonetics, business English, media discourse, technical translation, pedagogy; e-mail: phill.yield@gmail.com. ORCID: https://orcid.org/0000-0002-9728-9458 